\title{
Collaborative Learning Development Method for Data Structure Course Case Study : Students at Computer System Department Andalas University
}

\author{
Dodon Yendri ${ }^{1}$, Muhammad Hafiz Hersyah ${ }^{2}$ \\ \{dodon@fti.unand.ac.id ${ }^{1}$, mohammadhafizhersyah@it.unand.ac.id ${ }^{2}$ \} \\ ${ }^{1,2}$ Computer System Department, Information Technology Faculty, Andalas University, Padang, \\ Indonesia
}

\begin{abstract}
Majority of universities on today era had prioritize quality as both of culture and competitive advantage. Supporting one of the policies from the government in quality improvement, to apply competency standards in every department that possess behavior value, knowledge, general skills and specific skills. Due to such requirements, the curriculum design must be able to achieve competency objectives. This research is commencing collaborative learning learning method in class where in every meeting, the students are forming focus group discussion. In addition, the open source based ilearn media is being optimized for daily interaction and to distribute syllabus, course material, task assignment and completion. The result of the research shows that $62 \%$ respondent founds the ilearn media is very convenient, $31 \%$ respondents stated the media is apporiate. The percentage group of $47.67 \%$ from the students claimed the holistic comprehension, $45.35 \%$ asserted their general understanding and only small percentages 6.98 declare not grasp the concept. This matter is triggred by the absence of the students itself. The application of collaborayive learing method also able to stimulate the passion of learning in following description, $39.53 \%$ asserted their fully enthusiam, $45.35 \%$ stated eagerness and the rest $15.12 \%$ are less ardency. Significantly, this method is able to boost the learning style and also able to polish up the final mark in $55.81 \%$, additionally formed the students softskill decently.
\end{abstract}

Keywords: Collaborative, learning, Quality, Ilearn, Competency.

\section{Introduction}

The KKNI-based curriculum has been implemented since 2017 in the Computer Systems Department Faculty of Technology, Andalas University. Data Structure Subject in the curriculum structure are the core compulsory courses of study programs offered in semester II (two) with a weight of 2 credits. This course is a compulsory subject where to take this course must pass the Algorithm and Problem Solving course. However, because this course is offered in the semester of the package, the requirements can be passed. This means that all students can take all courses offered in semester II even though they have not graduated.

This study discusses how to provide a good and structured space so that the data stored can be read easily so that high performance from a computer application can be obtained. With 
today's complex problems, IT support for science and technology must be a major concern. Application performance depends not only on the algorithm used but also depends on the selection of the data structure. With the selection of a good data structure complex problems can be simplified, so that algorithms can be used efficiently, important operations can be executed with smaller resources, more memory can be saved and shorter execution time.

Data Structure subject conncetion with other subjects especially with programming courses are very narrow, such as Object-Oriented Programming, Multi Platform Programming and Embedded Programming System which are widely used in the final assignment of students. Contribution of competence or achievement of learning subjects Data Structure in the curriculum of the study program is the basis for the achievement of competencies in graduates of computer systems study programs.

Both of the author has been teaching Data Structure subjects since this curriculum took effect. The applied learning method is the SCL Cooperative Learning method. To achieve the competencies that are expected to have been carried out several innovations in various ways, such as presentation techniques, course material delivery, development of teaching materials and assessment systems. Teaching materials are developed based on technological developments arranged in the form of power points and modules that will be implemented hands-on both in the classroom and in the laboratory. This method requires preparations that are a little complicated when compared to other methods. One of the weaknesses of this model is that if there are lazy students and want to be in charge in a large group, it will influence other group members so that the group does not functioned properly.

From the assessment carried out on the Data Structure subject in Even semester 2017/2018, consist of class A and class B, obtained the distribution of values as shown in Figure 1 below.

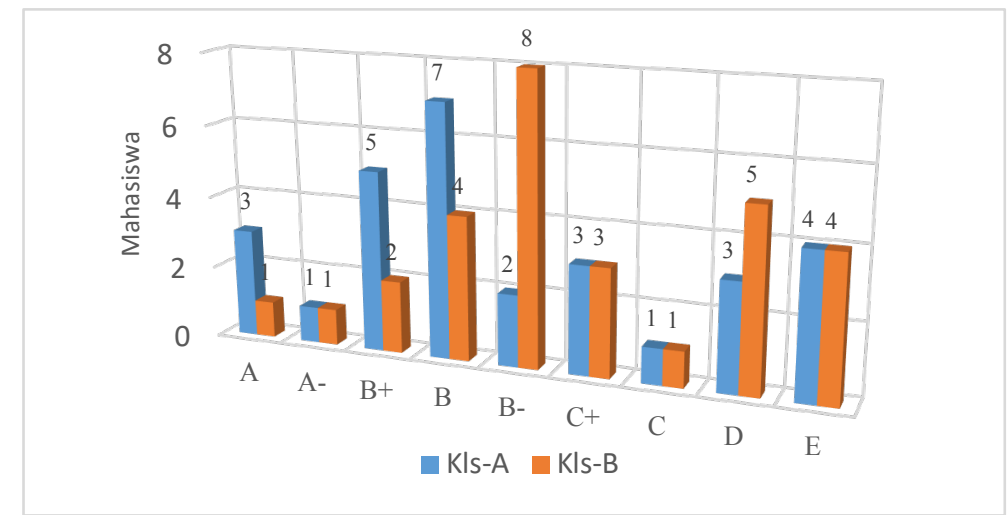

Figure 1. Distribution Graphic of Students Mark

Based on learning outcomes as shown in Figure 1 above, only few students achieve very good grades. from the two classes (A and $\mathrm{B}$ ) only 4 people $(6.9 \%)$ received $\mathrm{A}, 2$ people $(3.45 \%)$ A-scores, 7 people $(12.07 \%) \mathrm{B}+$ scores, 11 people $(18,97 \%) \mathrm{B}$ value, 10 people $(17.24 \%) \mathrm{B}-$ value, 6 people $(10.36 \%) \mathrm{C}+$ and 2 people $(0.03 \%) \mathrm{C}$ values. Other than that (16 people or $27.59 \%)$ ) did not pass with the $\mathrm{D}$ and $\mathrm{E}$ grades. There were 5 students who got an $\mathrm{E}$ score due to not taking the final semester exam due to the presence of those who did not meet the $75 \%$ requirement. Based on the achievements of learning and analysis carried out, the author 
developed a learning method using the Collaborative Learning method in the Data Structure subject.

\subsection{Problem Formulation}

From the description and analysis that has been carried out on the acquisition of each rating weight, the formulation problem are:

1 How to evaluate the learning outcomes of each meeting.

2 How to develop learning methodsin order to improve the outcome.

3 How to develop a strategies so that students do the tasks given.

4 How to increase the motivation of students to learn autonomously and find new sources of knowledge.

\subsection{Research Objectives}

The objectives of this learning development study are:

1 Evaluate learning outcomes through Semester Learning Plans (RPS)

2 Develop learning methods in order to improve learning outcomes.

3 Creating a learning environment that is student-centered, integrated and fosters an atmosphere of cooperation and mutual respect.

4 Getting the results of the application of the development of collaborative learning learning methods with the formation of student soft skills properly.

\subsection{Research Benefits}

The benefits of the research you want to expect are:

1. Grow motivation, interest or passion for student learning

2. Guarantee the development of student personality activities.

3. Instill and develop the values and main attitudes expected in good learning habits.

4. Provide opportunities for students to express creatively.

5. Stimulate desire and motivate students to learn continuously, explore and innovate something new.

6. Train students to be able to take responsibility for their own efforts.

\section{Theoretical Background}

\subsection{Learning Process}

Learning had to prioritise the best results. To obtain optimal learning results, the process must be done well too. [4] states that the process is: (1) a series of changes (events) in the development of something; (2) a series of actions, preparations, or processing that produce products and (3) cases in court. Rustaman [10] argues that the learning process is a process in which there is an activity of interaction between teacher and students and reciprocal communication that takes place in educational situations to achieve learning goals. In the learning process, teachers and students are two components that cannot be separated. Between these two components interaction must be intertwined to support each other so that student learning outcomes can be achieved optimally. The learning process is the process of interaction of students with educators and learning resources in a learning environment. 


\subsection{Learning Method}

Learning method is a way to implement plans that have been prepared in the form of real and practical activities in order to achieve the expected learning goals. The following are learning methods according to some experts:

1. Geriach Ely in his book Strategies in the Learning Process [8]

Learning methods are ways chosen to deliver lessons in a particular teaching environment, which includes the nature, scope and sequence of activities that can provide learning experiences to students.

2. Nana Sudjana [13]

The learning method is, "Learning methods are ways that the teacher uses in making relations with students during the course of teaching"

3. M. Sobri Sutikno [14]

Learning methods are ways of presenting subject matter conducted by educators so that learning processes occur in students in an effort to achieve goals.

4. Salamun [13]

Learning methods are a different way of achieving different learning outcomes under different conditions.

5. The characteristics of a good learning method are as follows: [12][14]

a. It is flexible, flexible and has the power that matches the student's character and material

b. Functional in uniting theory with practice and delivering students to practical abilities.

c. Does not reduce material, and even develop material.

d. Provide flexibility for students to express their opinions.

e. Being able to put the teacher in the right position, honored in the whole learning process.

\subsection{Learning Model}

Learning models are derived from differences in student characteristics that vary. Because students have various personality characteristics, habits, ways of learning that vary between individuals with each other, the learning model is not fixed only on certain models. According to [2] the learning model is a pattern that is used as a guide in planning classroom learning. The learning model is a conceptual framework that describes a systematic procedure in organizing learning experiences to achieve certain learning goals, and serves as a guide for learning designers and instructors in planning teaching and learning activities (Soekamto in Trianto (2009).

From the opinion above, it can be concluded that the learning model is a conceptual framework that describes patterns or procedures systematically in organizing learning which serves as a guide for teachers in planning and implementing learning. In teaching a subject the learning model must be chosen that is most suitable for the objectives to be achieved. Therefore, in choosing a learning model must have considerations. There are three things to consider that need to be done, namely (1) subject matter, (2) the level of cognitive development of students, and (3) facilities or facilities available, so that the learning objectives that have been set can be achieved. 


\subsection{Collaborative Learning Method}

Collaborative learning is a situation where there are two or more people learning or trying to learn something together in one group. Unlike learning alone, people involved in collaborative learning utilize the resources and skills of each other (asking for information from one another, evaluating ideas with each other, monitoring each other's work, and caring for each other and having responsibilities with each other in one group).

According to [16]), collaborative learning is a group learning process that each member contributes information, experience, ideas, attitudes, opinions, abilities, and skills he has to jointly improve the understanding of all members. [3] describe that the method of collaborative learning is a learning approach used for teaching and learning that involves a group of students working together to solve problems, complete tasks or produce products. This method is based on the idea that learning is a natural social action with participants discussing with each other. Through this discussion the learning process takes place. Therefore, collaborative learning allows each student to understand the entire section of material discussion. This is different from general study groups where not all group members understand the material being learned.

The collabotive learning method makes all students have an equal understanding of material. According to [3] collaborative learning methods have following several characteristics

1. Students have a common goal

2. Student-centered learning

3. Students build their own knowledge framework

4. Learning is not the transmission of knowledge, but involves the regulation of class situations

5. The curriculum is considered a learning device, material and resources

Based on the above characteristics it can be concluded that with the application of collaborative learning methods it is expected that students can build their own knowledge framework so they can learn practical thinking. Furthermore [11] explains the differences in conventional methods with collaborative learning as shown in Table 1 below.

Tabel 1. The Differences in Method Leaning : Conventional and Collaborative Learning

\begin{tabular}{|c|c|c|}
\hline No & Conventional & Metode Collaborative Learning \\
\hline 1. & Lecturer centered environment & Students centered environment \\
\hline 2. & Lecturer controlled the learning scope & Students controlled their learning scope \\
\hline 3. & Lecturer centered responsibilities & Students Centered Responsibilities \\
\hline 4. & $\begin{array}{l}\text { Lecturer as instructure and decision } \\
\text { makers }\end{array}$ & $\begin{array}{l}\text { Lectuerer as fasilitator, students as decision } \\
\text { maker. }\end{array}$ \\
\hline 5. & Competitive learning experience & Cooperative, collaborative and independent. \\
\hline 6. & $\begin{array}{l}\text { Small group of lecturer decide task and } \\
\text { assignment. }\end{array}$ & Authentic \\
\hline 7. & Leraning in a classroom & Learning could commence outside of the class \\
\hline 8. & Content- Oriented & Information Processing-oriented \\
\hline 9. & Knowledge aquisition by drilling & $\begin{array}{l}\text { Construct knowledge and make decision } \\
\text { regarding learning. }\end{array}$ \\
\hline
\end{tabular}

Depending on its types, there are four class types based on collaborative learning, that are:

1. Teacher and Students sharing informations.

2. Delegating task 
3. Lecturer are mediator

4. Heterogen types of students.

The above one and two attributes relate to the change of relationship between the instructor and the learners. The third attribute relates to a new approach of teaching submission during the learning process, and the fourth attribute states class content or collaborative learning.

\section{Methodology}

This research is a development research with stages of analysis (analysis), design (design), implementation (implementation) and evaluation (evaluation). The stages of research in this development method are presented in Figure 3.1 below.
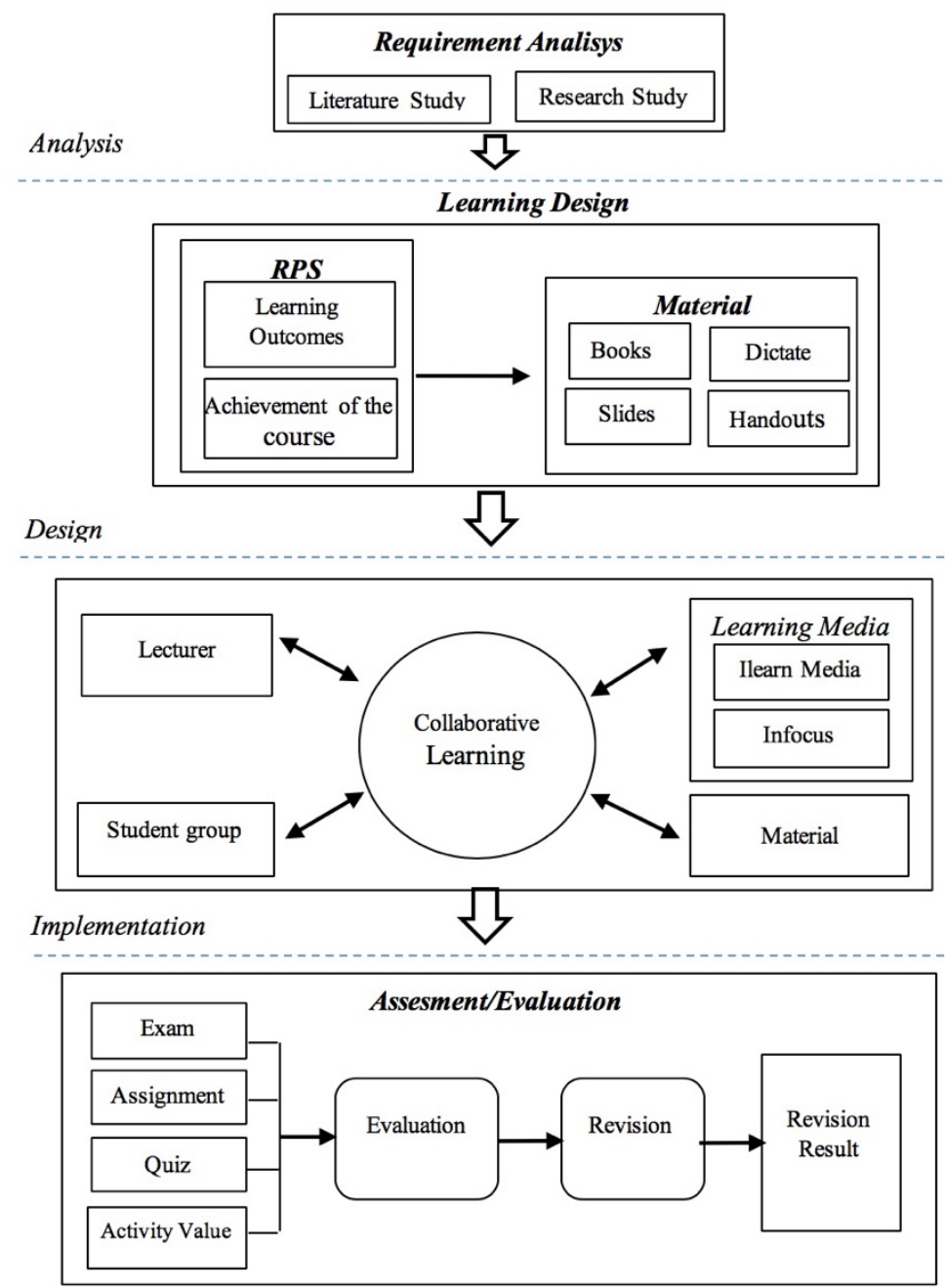

Assesment and Evaluation

Figure 3.1. Research Methods 
Based on Figures 3.1. this reserach is consisting of several stages :

1. Requirements Analysis

Analysis begins with reading the literature and the results of research on preexisting learning methods. Some needs and variables are identified as references in conducting research. After getting a clear picture of the literature and the results of the research and the variables needed.

2. Design

After obtaining a clear picture of the research variables, then proceed with the design (design). There are two types of designs that are carried out, namely (1) designing or repairing RPS, and (2) designing teaching materials. The design or improvement of the RPS is done by determining the learning outcomes and learning outcomes of the study program (achievement of the course). While the design of teaching material is done to make and fulfill the results of the course using references such as books, dictates, presentation slides and handouts.

3. Implementation

The implementation phase is the third stage after the design is done. By referring to the RPS that has been compiled / developed and the teaching material that has been made, then it is then implemented into the learning process using collaborative learning learning models. In its implementation the lecturer presents lessons based on the material that has been compiled on the RPS by using prepared media such as Infocus, the Ilearn application.

All participants pay attention to the lecturers giving explanations for five to ten minutes about the material learned at the meeting. Next the lecturers divide the material to all groups that have been prepared. Each group leader divides the material to all members, so that all the material learned is understood by all group members. As a learning or reference material, students can download it at any time to Andalas University Ilearn as a reference.

After each group member learns the material they get, then each member takes turns explaining to the members in one group until all members understand all the material provided. Then each member makes a resume and presentation materials using power points to be presented to other groups. Each group appointed their team to make presentations using focus media as presentation media. The implementation of this learning method is carried out for seven weeks after the Mid Semester Examination until the last meeting before the Semester Final Examination by observing each meeting.

4. Assessment and Evaluation

The final stage of this teaching material development research is conducting an evaluation and evaluation of learning outcomes. There are two assessments that will be carried out in this study, namely initial assessment and final assessment. The initial assessment is used to obtain an overview of the students' initial abilities before collaborative learning learning methods are implemented, while the final assessment is an assessment by paying attention to the final grades of students. The initial assessment is done by pre-test, test- 1 and test- 2 .

The final assessment consists of two activities, namely process assessment and outcome assessment. Process assessment is the activeness value of the number of points students have collected during topic review, discussion, working on assignments, presentations, asking questions, answering questions and providing additional answers at each meeting. While the assessment of the results is an assessment of the tasks 
obtained from the number of tasks completed and the level of truth done, the value of UTS and UAS which is carried out on a scheduled basis and arranged by the academic department of Andalas University. In addition to some of the assessment elements that have been explained, there are also assessments of each student's soft skills (such as communication skills, teamwork skills, receiving criticism and suggestions, and respecting the opinions of friends assessed when they prepare assignments and group presentations. Table 2 is an assessment guideline that will be conducted in research on the Development of Collaborative Learning Learning Methods in Data Structure Courses.

Table 2. Final Grades Calculation

\begin{tabular}{lcl}
\hline No & Marking Components & Weight (\%) \\
\hline 1. & Result Assessment & $\mathbf{6 0}$ \\
a. & Mid Term Evaluation & 20 \\
b. & Final Term Evaluation & 25 \\
c. & Assignment Evaluation & 15 \\
2. & Process Assessment (Softskills) & $\mathbf{4 0}$ \\
a. & Group Presentation & 7,5 \\
b. & Discussion & 7,5 \\
c. & Answering Question & 7,5 \\
d. & Accepting Advices & 5,0 \\
e. & Team Collaboration & 7,5 \\
f. & Accepting other opinion & 5,0 \\
\multicolumn{2}{c}{ Total } & $\mathbf{1 0 0}$ \\
\hline
\end{tabular}

Furthermore, evaluations were also conducted on the results of learning outcomes by requesting responses from respondents by sending questionnaires to all students. Questionnaire questions are designed using the Google Form application and then sent via WhatsApp or Facebook to each student. The answers to the questionnaire delivery are then processed using the Microsoft Excel application for quantitative analysis. If the evaluation results do not meet the expected learning outcomes, improvements or revisions will be made to get the desired results.

\section{Result and Discussion}

With this method, it is expected that all students have the same understanding of the material given. Giving assignments and responsibilities to all members can trigger caring and want to know more about what is being understood. Interactional theory views learning as a process and building meaning through social interaction is the basis of collaborative methods.

As technology for learning (technology for instruction), collaborative learning involves active participation of learning participants by minimizing differences between individuals both from the level of intelligence, gender, ethnicity and region of origin. Collaborative learning has added momentum to formal and informal education from the two powers that met, namely:

(1) realization of practice, that life outside the classroom requires collaborative activities in life in the real world;

(2) foster awareness of social interaction in an effort to realize meaningful learning. 
Based on the two strengths of the collalaborative learning and classroom action research methods that have been carried out involving the second semester students of the Faculty of Information Technology Computer Systems Department of Andalas University who took Data Structure courses in the even semester 2018/2019 as many as 86 people (47 classes A and 39 class B) ) Broadly speaking, there are several research results obtained including:

1. RPS Revision on a particular chapter.

2. Swift access on Ilearn.

3. Collaborative learning methods application

4. Increased learning style on Collaborative learning.

5. Increased Marking result on Data Structure Course.

6. Established good soft skill in daily interaction.

\subsection{RPS Revision}

From learning implementation, on this collaborative learning methods, there should be several revision maintanied on RPS :

1. Rearrangement on Course Material.

The sequence of material studied greatly impacts students' understanding as a provision for subsequent learning. Well-prepared material will be able to improve students' understanding and learning methods on an ongoing basis.

\section{Learning Method Revision on each meeting}

Compared to the previous learning methods cooperative learning which emphasizes the concept of group work, assignment of tasks and questions, and the provision of materials in groups determined by lecturers in the classroom, but with collaborative learning methods lecturers fully give personal responsibility and must have mutual attitudes respect for others. All participants must have responsibility for their own learning outcomes, trying to find information to answer the questions they face themselves and respecting friends' opinions. This means that even though learning is divided into groups, each participant must be responsible for the tasks given to him. Thus the lecturer gives the participants the flexibility to search for and find out for themselves the material being discussed. The role of the lecturer is only as a facilitator who provides support but does not control the direction that has been prepared. And the assessment of the answers to the question groups was carried out by other groups.

\section{Implementing Ilearn Media as Interaction Medium.}

In learning Structure Data subjects the author uses Ilearn media as a medium of interaction with students, such as uploading RPS, teaching materials, sending assignments and answers and other information related to implementing learning. By using media Ilearn all aspects of learning can be monitored and controlled in a timely manner, such as the limitation of sending tasks, a system of assessment / evaluation, communication with students to be more effective and efficient.

\section{Evaluation System Adjustment}

Another thing that needs to be improved on the RPS is that the assessment system that is applied must be improved, where the component rating process is more improved. This means that the assessment of soft skills and attitudes becomes more attention. RPS repair / revision can be seen in appendix 1 . 


\subsection{Swift Access on Ilearn}

Based on the contents of the questionnaire distributed to students in the Data Structure subject, the results show that students can access Ilearn's media very well. This can be seen in Figure 3.2 below.

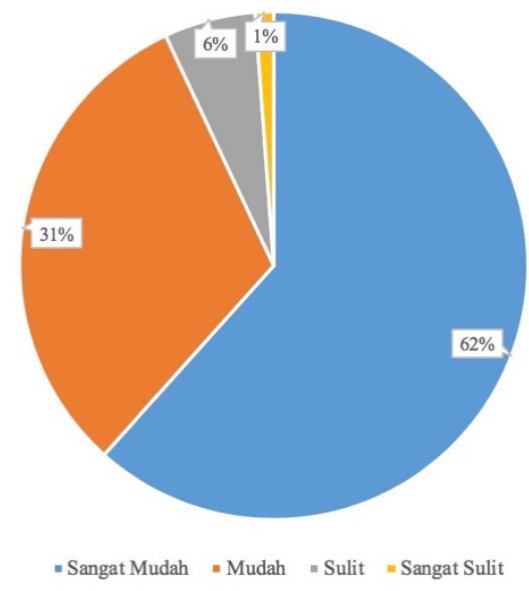

Figures 3.2. Ilearn usage

From Figure 3.2 above, $62 \%$ of students stated that it was "very easy" to access ILearn Media, $31 \%$ said "easy", only $6 \%$ said "difficult" and $1 \%$ "very difficult". The ease of accessing this media is because those who access are computer science students, but there are still those who say it is difficult and very difficult because they rarely attend lectures.

\subsection{Collaborative learning Advantages}

The results of the study show that the application of collaborative learning methods provides many benefits for students. The benefits obtained by students can be seen from three indicators, namely:

\section{a. Students Comprehension on Course Material}

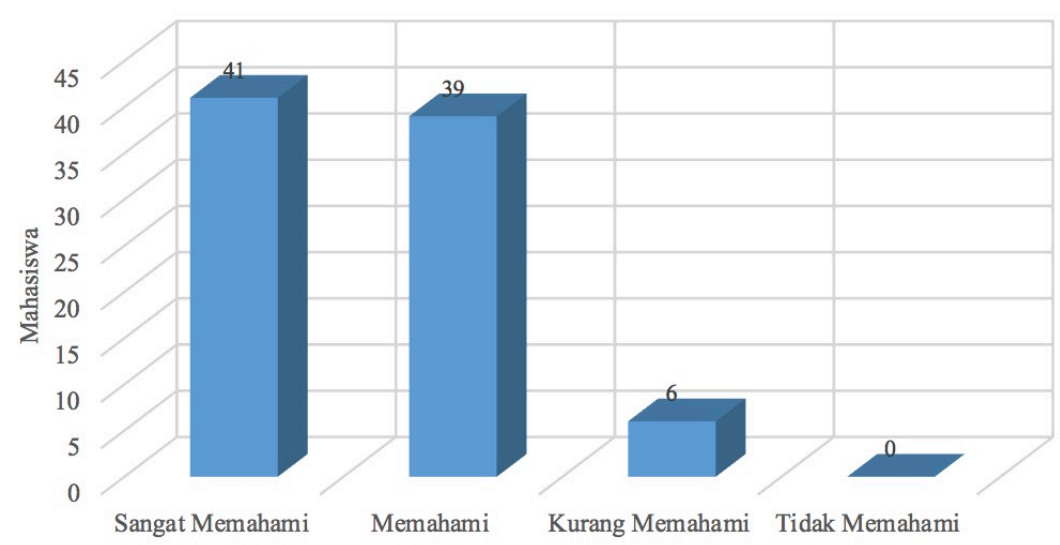

Figure 3.3 Students Comprehension on Course Material 
From Figure 3.3, it was found that 41 people $(47.67 \%)$ stated that they were "very understanding" of each material given, 39 people (45.35\%) "understood" and only a small number of students who did not understand were around 6 people $(6,97 \%)$. This is because they often do not enter every meeting.

\section{b. Ease of Learning}

Collaborative learning learning methods are very easy for participants. This is because the material studied must be sought by students so that each of them must account for what they are looking for. The ease of learning for participants in the Data Structure subject can be seen in the following Figure 3.4 .

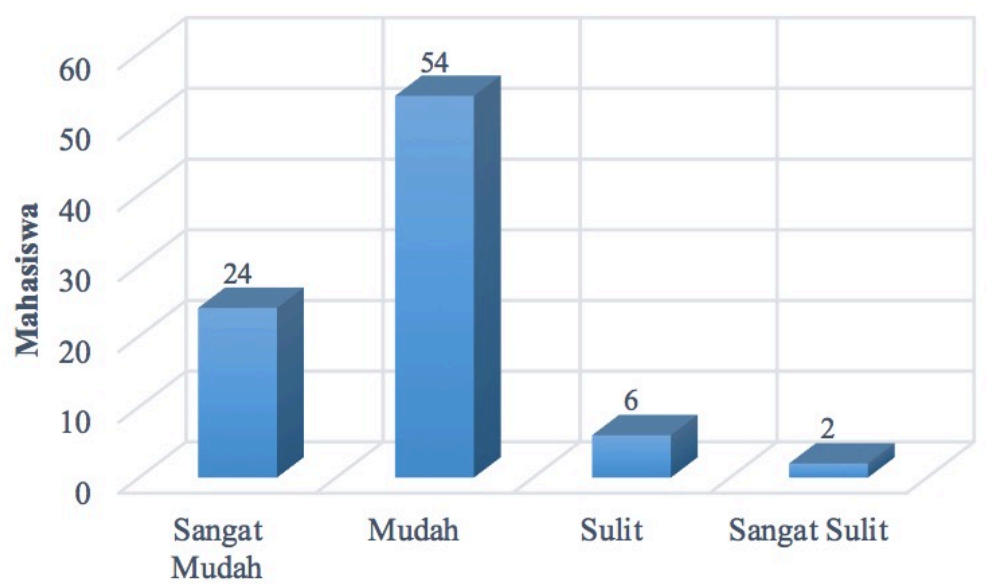

Figures 3.4 Ease of Learning Graphics

The graph in Figure 3.3 shows that 24 people $(27.91 \%)$ stated that it was "very easy" to learn using collaborative learning methods, most of which 54 people $(62.79 \%)$ stated "easy", only 6 people $(6.98 \%)$. ) states "difficult" and 2 people $(2.33 \%)$ say "very difficult". Students who say it is difficult and very difficult to follow because they are less able to work in teams.

a. Increasing Learning Appitite

Other benefits of applying collaborative learning learning methods can increase student enthusiasm in learning. Increased student learning enthusiasm can be seen as shown in Figure 3.5 below. 


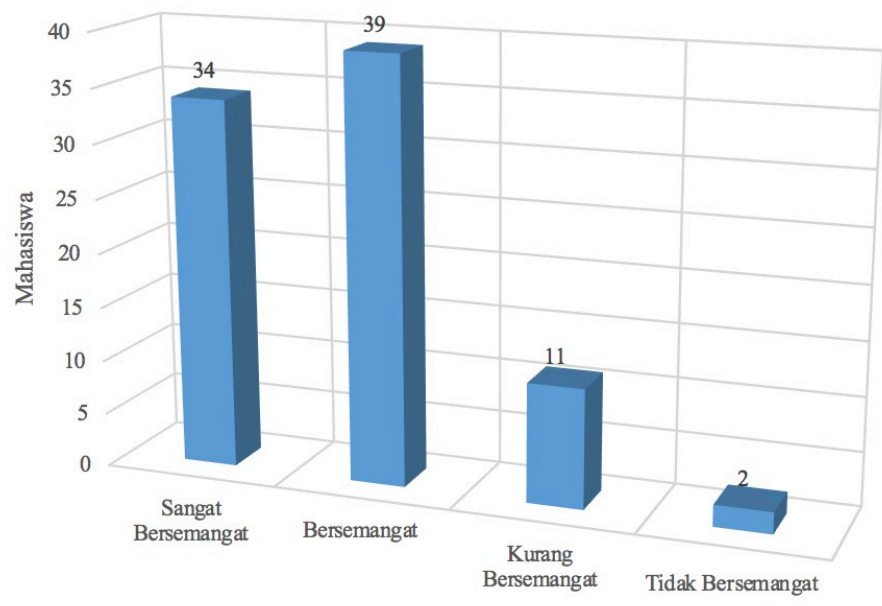

Figures 3.5 Learning Appitite

From the graph in Figure 3.5, it can be seen that 33 people (39.53\%) students stated that they were "very excited" in learning since collaborative learning methods were applied, 39 people $(45.35 \%)$ said they were "excited", 11 people $(12,79 \%)$ stated "lack of enthusiasm" and only $2(2.33 \%)$ students felt lack of enthusiasm. This is because they often do not enter and feel left behind by their diligent friends.

\subsection{Improved Students Learning Methods}

Improvement of student learning methods is measured by conducting an initial test or pretest before collaborative learning learning methods are applied. The initial ability of student learning methods can be seen in Figure 3.5. After obtaining an overview of the students' initial abilities, then the collaborative learning learning method is implemented with a four-week cycle in which every two weeks a test (test-1 and test-2) is carried out.

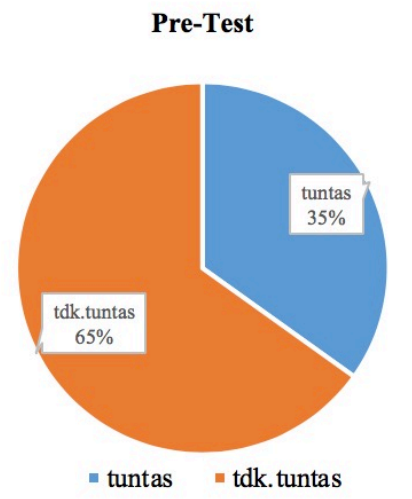

Figures 3.5 Pre-Test Evaluation

Based on the graph in Figure 3.5 it can be seen that more than half $(65 \%)$ of the participants' pre-test results were not completed. Improvement of student learning methods from pre-test to 
test- 1 and test- 2 after the application of collaborative learning learning methods can be seen in Figure 3.6 below

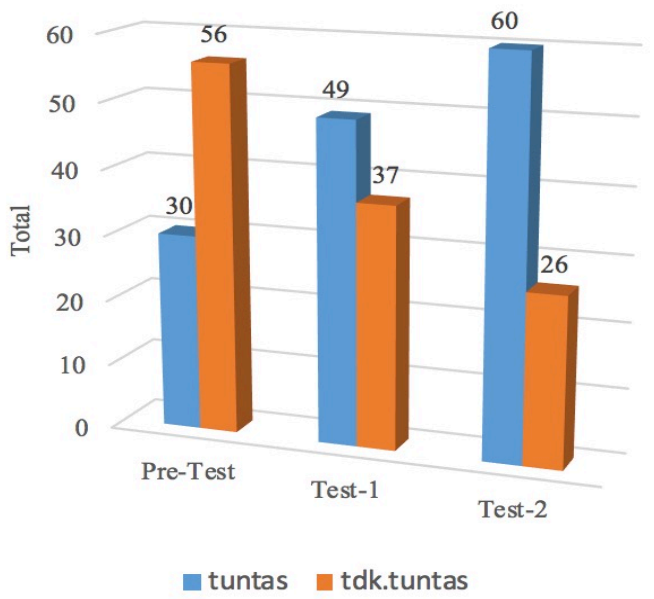

Figures 3.6 Student Learning Improvement Evaluation Chart

The graph in Figure 3.6 above shows that there is a significant jump after collaborative learning methods are applied. In Test- 1 there was an increase in the number of students completing from 30 to 49 students or by $22 \%$ than before (Pre-Test). Likewise in the implementation of Test-2, there was an increase of $12.8 \%$ from the implementation of the Test1 or $34.88 \%$ compared to the Pre-Test evaluation. This shows that the application of collaborative learning learning methods can improve the way students learn very well.

\subsection{Increased Distribution of Learning Outcomes}

Based on the final evaluation results of even semester 2018/2019 Data Structure subjects, it was found that the improvement of student learning outcomes was very good compared to even semester 2017/2018. Comparison of the distribution of student learning outcomes in Data Structure subjects in the even semester 2018/2019 and even semester 2017/2018 can be seen in Figure 3.7 as shown below :

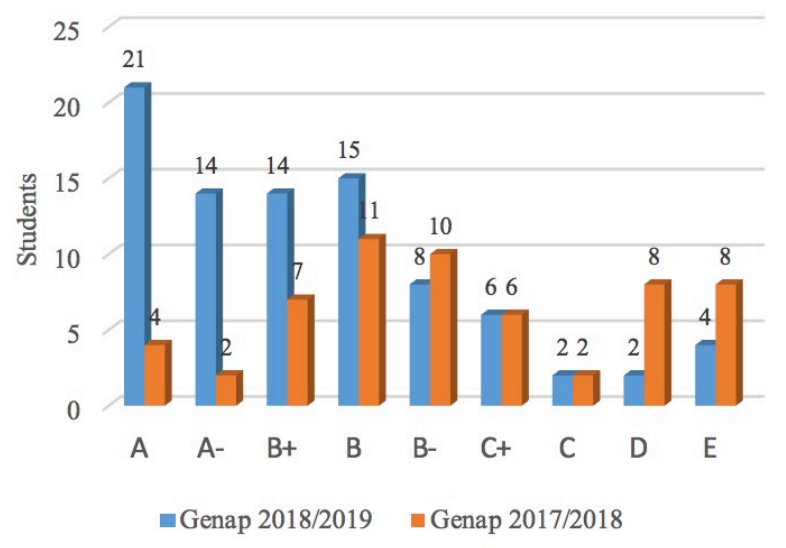

Figures 3.7 Students Final Mark Distribution Chart 
From Figure 3.7 it can be seen that many students get very good final grades in the even semester 2018/2019. Compared to the even semester 2017/2018 there is an increase in the acquisition of a significant final value, namely the value of $\mathrm{A}$ of 4 people in even semester $2017 / 2018$ to 21 people in the even semester 2018/2019 (19.78\%), for the A-value of 2 people in even semester $2017 / 2018$ to 14 people in even semester 2018/2019 (13.9\%), for grades B + from 7 people in even semester $2017 / 2018$ to 14 people in even semester $2018 / 2019(8.14 \%)$, grades B from 11 in even semester $2017 / 2018$ to 15 in even semester 2018/2019 (4.65\%). Whereas for the B-value there is a decline of 10 people in the even semester $2017 / 2018$ to 8 people in the even semester 2018/2019. Then for the $\mathrm{C}+$ and $\mathrm{C}$ values it remains 6 people $(0 \%)$, and the D and $\mathrm{E}$ values occur again in successive increases from 8 to $2(6.96 \%)$ and 8 to 4 $(4.65 \%)$.

Overall the application of collaborative learning learning methods can improve student learning outcomes in Data Structure subjects in even semester 2018/2019 which is equal to $55.81 \%$ compared to even semester $2017 / 2018$ who have not used collaborative learning methods.

\subsection{Establish Softskill in Daily Interaction}

One important benefit obtained from the application of collaborative learning learning methods is the formation of student softskills in learning. Student softskill can be formed from several assessment components including the courage of students in asking questions and answering questions in the classroom, accepting criticism or suggestions, being able to cooperate and respect each other's opinions and courage to present the results of the discussion in front of the class. Figure 3.8 shows a picture of student softskills in learning Data Structure subjects from both classes.

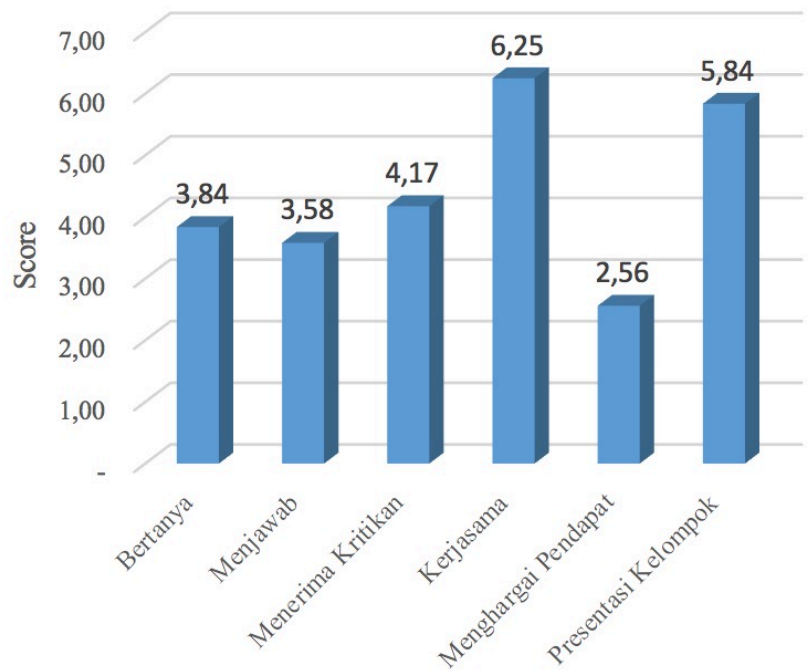

Figures 3.8 Student Soft Skill Chart

From Figure 3.8 it can be seen that all elements of soft skill formation can be done by students. Collaboration and group presentations have quite good values $(6.25 \%$ and $5.84 \%)$, this 
is because when discussing students must be able to work together in their groups, because each has their own duties and responsibilities and then must explain to other friends in the group. Furthermore, the results of group discussions are then presented to other groups in the class. It's just that there are still a small percentage of students $(2.56 \%)$ who cannot appreciate their friends' opinions because they are defeated by their own ego. In general it can be concluded that the application of collaborative learning learning methods can form student softskills well.

\section{Conclusion}

From classroom action research that has been done with the application of collaborative learning learning methods to 86 respondents or students can be drawn several conclusions, namely:

1. Most students (62\%) say 'very easy' and $31 \%$ say 'easy' to access the Ilearn Unand learning media application.

2. Understanding the material by students at each meeting amounted to (47.67\%) stating "very understanding", $45.35 \%$ "understanding" and only a small proportion who did not understand $(6.97 \%$. This is because they are often absent) every meeting.

3. More than half $(62.79 \%)$ of students stated "easy" learning using collaborative learning methods, $27.91 \%$ stated "very easy" and very few said it was difficult and very difficult. This is because they are less able to work in teams.

4. Can foster a spirit of student learning that is $39.53 \%$ of students said "very excited", $45.35 \%$ said "excited" and the remaining 12.79\% said "lackluster" and 2.33\% felt "not excited". This is because they feel left behind with friends because they often don't attend class.

5. Significantly increased student learning methods amounted to $34.88 \%$ after evaluation of test- 1 and test- 2 compared to the results of the pre-test.

6. Increased the final grade of Even semester 2018/2019 students compared to Even semester $2017 / 2018$ which is $55.81 \%$.

7. Application of collaborative learning learning methods can form student softskills well.

\section{References}

[1] Agus Suprijono. Cooperative Learning: Teori dan Aplikasi PAIKEM, Yogyakarta : Pustaka Pelajar. (2009)

[2] Ahmadi, Abu, . Strategi Belajar Mengajar. Pustaka Setia. Bandung. (1997)

[3] Armiati, Sari dan Husni Sastramihardja. CollaborativeLearning Framework, (2007) http://journal.uii.ac.id/index.php/Snati/article/viewFile/161411389. (Diakses pada tanggal 7 Juli 2019).

[4] Bruffee, Kenneth A. Collaborative Learning and the Conversation of Mankind, College English 46, no. 7 (November 1984): 635-52.

[5] Depdiknas. Kamus Besar Bahasa Indonesia. Edisi ke-III. Jakarta: Balai Pustaka. (2006)

[6] First International Conference. LCT 2014 Held as Part of HCI International 2014 Heraklion, Crete, Greece, June 22-27, 2014, Proceedings, Part II, HCI2014 International, Springer

[7] Guzdial, Mark. Information Ecology of Collaborations in Educational Settings: In>uence of Tool. In Proceedings of Computer-Supported Collaborative Learning (1997). 
[8] Gerlach dan Ely. Teaching \& Media: A Systematic Approach. Second Edition, by V.S. Gerlach \& D.P. Ely, 1980, Boston, MA: Allyn and Bacon. Copyright 1980 by Pearson Education (1997)

[9] John Trimbur, Consensus and Difference in Colla borative Learning, College, English 51, no. 6 (1989)

[10] Kristyana, Lidya Ndaru. Bernyanyi Sebagai Strategi Untuk Meningkatkan Kemampuan Berbicara Anak Usia Dini Di TK Bakti Mulia Mejasem Kramat, Kabupaten Tegal. Skripsi. UNNES. Semarang. (2014)

[11] Kriswadani. Efektifitas CollaborativeLearning terhadap Prestasi Belajar Ditinjau dari Konsep Diri Siswa Kelas V Sekolah Dasar di Kecamatan Sidorejo Kota Salatiga, Thesis, Program S1 Pendidikan Guru Sekolah Pendidikan Guru Sekolah Dasar. Universitas Kristen SatyaWacana (2009).

[12] Pupuh Fathurrohman \& M. Sobry Sutikno. Strategi Belajar Mengajar melalui Penanaman Konsep Umum dan Islami, Bandung: Rafika Aditama. (2007)

[13] Sudjana, Nana. Dasar-dasar Proses Belajar Mengajar. Bandung. Sinar Baru Algensindo. (2005)

[14] Sutikno, Sobry M. Belajar dan Pembelajaran. Prospect. Bandung. ( 2009)

[15] Slavin, Robert E. Cooperative Learning Teori, Riset dan Praktik. Bandung, Nusa Media. (2008)

[16] Sudarman. Penerapan Metode Collaborative Learning untuk Meningkatkan Materi Mata Kuliah Metgdologi Penelitian . Jurnal Pendidikan Inovatif, Vol. 3 No.2, hal.94-100. (2008)

[17] Trimbur, John. Consensus and Difference in Collaborative Learning, College English 51, no. 6 (1989)

[18] Winkel, W.S. Psikologi Pengajaran. Yogyakarta:Media Abadi. (2004)

[19] Wiki Writing. Collaborative Learning in the College Classroom. Edited by Robert E. Cummings and Matt Barton. (2008) 